\title{
Complete genome sequence of Arthrobacter sp. strain FB24
}

\author{
Cindy H. Nakatsu ${ }^{1 *}$, Ravi Barabote ${ }^{2}$, Sue Thompson ${ }^{2}$, David Bruce ${ }^{2}$, Chris Detter ${ }^{2}$, Thomas \\ Brettin $^{2}$, Cliff Han ${ }^{2}$, Federico Beasley ${ }^{1}$, Weimin Chen ${ }^{1}$, Allan Konopka ${ }^{3}$, and Gary Xie ${ }^{2}$ \\ ${ }^{1}$ Department of Agronomy, Purdue University, West Lafayette, IN \\ ${ }^{2}$ Los Alamos National Laboratories, Los Alamos, NM \\ ${ }^{3}$ Pacific Northwest National Laboratory, Richland, WA \\ *Correspondence: Cindy H. Nakatsu (cnakatsu@purdue.edu)
}

\begin{abstract}
Arthrobacter sp. strain FB24 is a species in the genus Arthrobacter Conn and Dimmick 1947, in the family Micrococcaceae and class Actinobacteriaceae. A number of Arthrobacter genome sequences have been completed because of their important role in soil, especially bioremediation. This isolate is of special interest because it is tolerant to multiple metals and it is extremely resistant to elevated concentrations of chromate. The genome consists of a 4,698,945 bp circular chromosome and three plasmids $(96,488,115,507$, and 159,536 bp, a total of 5,070,478 bp), coding 4,536 proteins of which 1,257 are without known function. This genome was sequenced as part of the DOE Joint Genome Institute Program.
\end{abstract}

\begin{abstract}
Abbreviations-IMG- Integrated microbial genomes, DOE-JGI- Department of Energy Joint Genome Institution, NCBI- National Center for Biotechnology Information (Bethesda, MD, USA), RDP- Ribosomal Database Project (East Lansing, MI, USA)
\end{abstract}

\section{Introduction}

Arthrobacter sp. strain FB24 was isolated from a microcosm made from soil collected at an Indiana Department of Transport facility in Seymour, Indiana. This site was of particular interest because the soils were contaminated by mixed waste, both petroleum hydrocarbons and extreme metal (chromium and lead) levels [1]. Details of microcosm enrichment and isolation procedures used to obtain the Arthrobacter strain have been described previously [2]. This isolate was of particular interest because of its extreme resistance to chromate $[3,4]$. This work is a part of a larger study determining the compositional and functional diversity of bacterial communities in soils exposed to long-term contamination with metals [5-7].

\section{Classification and features}

Arthrobacter sp. strain FB24 is a high G+C Grampositive member of the Micrococcaceae (Figure 1, Table 1). The strain is a facultative, non-motile aerobe with characteristic morphology of rod-shaped cells (Figure 2) that become coccoid in stationary phase. Strain FB24 is able to use a number carbon sources for growth, including glucose, fructose, lactate, succinate, malate, xylose and aromatic hydrocarbons (hydroxybenzoates, phthalate). Additionally, this Arthrobacter sp. strain is resistant to multiple metals: arsenate, arsenite, chromate, cadmium, lead, nickel, and zinc.

\section{Genome sequencing information Genome project history}

Arthrobacter sp. strain FB24 was chosen for sequencing by DOE-JGI because of its extreme resistance to chromate. Table 2 presents the project information and its association with MIGS version 2.0 compliance [25].

\section{Growth conditions and DNA isolation}

The FB24 culture used for DNA extraction was started from the glycerol stock (stored at $-80^{\circ} \mathrm{C}$ ) that was made from the original isolate. Cells were streaked onto a $0.1 \times$ nutrient agar plate, incubated at $30^{\circ} \mathrm{C}$, then a single colony was used to grow a culture in $0.25 \times$ nutrient broth (NB) (Difco, USA). Total genomic DNA was extracted from cells grown in liquid culture using the standard CTAB procedure [26]. 


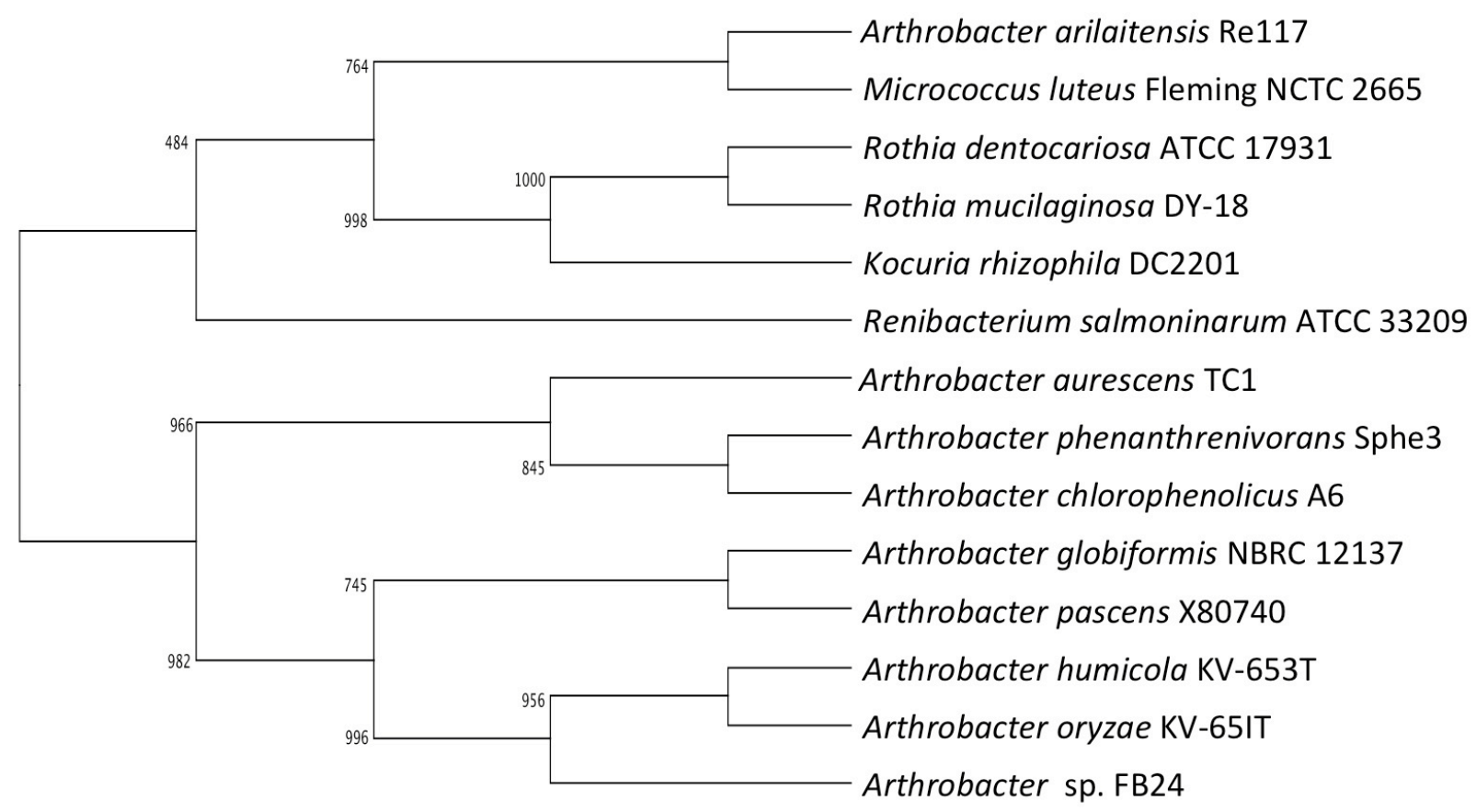

Figure 1. Phylogenetic tree of Arthrobacter strain FB24 relative to nearest neighboring Arthrobacter type strains and Micrococcaceae strains with finished genome sequences: A. arilaitensis re117 (FQ311476) [8], A. aurescens TC1 (NC_008709) [9], A. chlorophenolicus A6 (NC_011886), A. phenanthrenivorans Sphe3 (CP002379 [10], Kocuria rhizophila DC2201, Microccus luteus Fleming NCTC 2665, Renibacterium salmoninarum ATCC 33209, Rothia dentocariosa ATCC 17931, and Rothia mucilaginous DY-18. The sequences were aligned in ClustalX and a consensus tree was generated using a 1,000× repeated bootstrapping process [11,12].

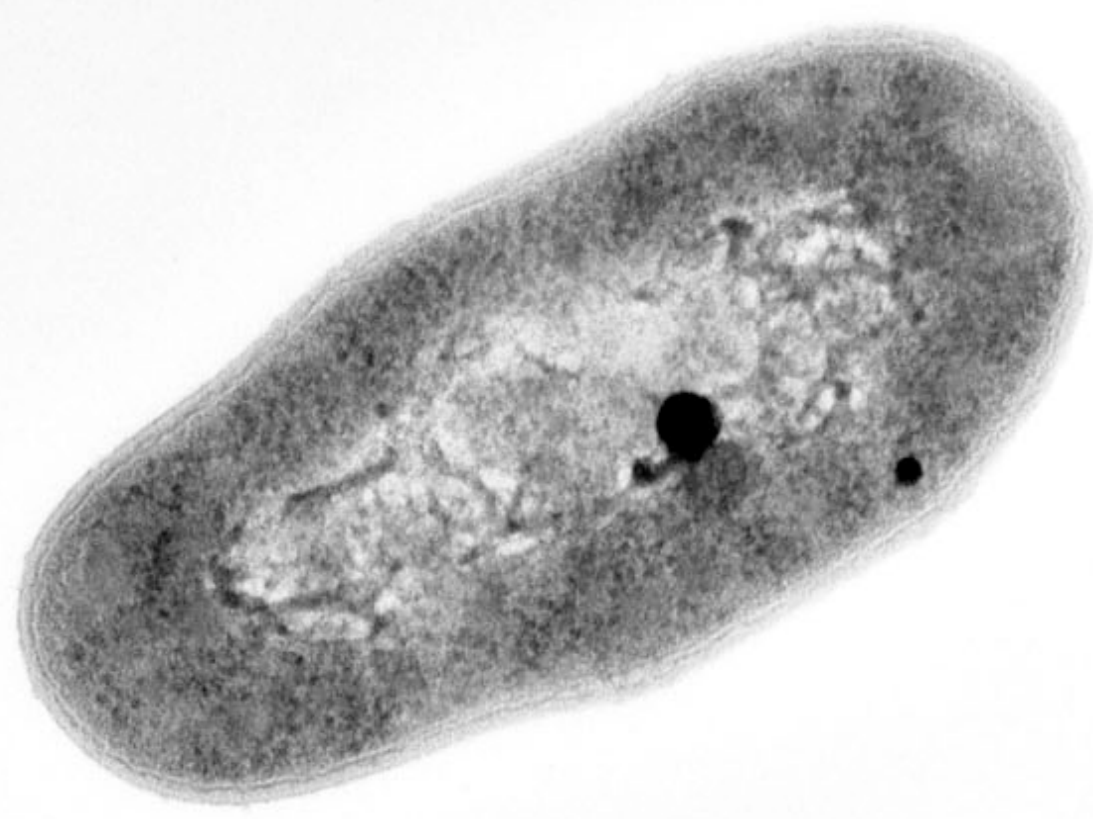

Figure 2. Transmission electron micrograph of Arthrobacter sp. strain FB24. Cells were grown in nutrient broth for $15 \mathrm{~h}$ ( early stationary phase), fixed in 3\% glutaraldehyde in $0.1 \mathrm{M}$ cacodylate buffer, then fixed in reduced osmium, followed by a series of ethanol dehydration steps. Cells are then embedded in Spurr resin, stained with uranyl acetate and Reynold's lead citrate. Image was captured on Kodak SO-163 film at 33,000× magnification. 
Table 1. Classification and general features of Arthrobacter strain FB24

\begin{tabular}{|c|c|c|c|}
\hline MIGS ID & Property & Term & Evidence code $^{\mathrm{a}}$ \\
\hline & & Domain Bacteria & TAS [13] \\
\hline & & Phylum Actinobacteria & TAS [14] \\
\hline & & Class Actinobacteria & TAS [15] \\
\hline & Current classification & Order Actinomycetales & TAS [15-18] \\
\hline & & Family Micrococcaceae & TAS $[15-17,19]$ \\
\hline & & Genus Arthrobacter & TAS $[17,20-23]$ \\
\hline & & Species Arthrobacter sp. & TAS [14] \\
\hline & & Type strain & TAS [15] \\
\hline & Gram stain & Positive & IDA \\
\hline & Cell shape & Polymorphic: Coccus to rod shape & IDA \\
\hline & Motility & Non-motile & IDA \\
\hline & Sporulation & Non-sporulating & IDA \\
\hline & Temperature range & $4-37^{\circ} \mathrm{C}$ & IDA \\
\hline & Optimum temperature & $30^{\circ} \mathrm{C}$ & IDA \\
\hline & Carbon source & $\begin{array}{l}\text { Yeast extract, glucose, fructose, lactate, } \\
\text { succinate, malate, xylose, } \\
\text { hydroxybenzoates, phthalate }\end{array}$ & \\
\hline & Energy source & $\begin{array}{l}\text { Yeast extract, glucose, fructose, } \\
\text { lactate, succinate, malate, xylose, } \\
\text { hydroxybenzoates, phthalate }\end{array}$ & \\
\hline & Terminal electron receptor & Oxygen or nitrate & IDA \\
\hline \multirow[t]{2}{*}{ MIGS-6 } & Habitat & Soil & TAS [1] \\
\hline & Isolation & $\begin{array}{l}\text { Chromate and xylene enriched micro- } \\
\text { cosm composed } \\
\text { of anthropogenically disturbed soils }\end{array}$ & TAS [2] \\
\hline MIGS-6.3 & Salinity & & \\
\hline MIGS-22 & Oxygen & Facultative aerobe & IDA \\
\hline MIGS-15 & Biotic relationship & Free-living & IDA \\
\hline MIGS-14 & Pathogenicity & Non-pathogenic & NAS \\
\hline MIGS-4 & Geographic location & Seymour, Indiana, USA & TAS $[1,2]$ \\
\hline MIGS-5 & Sample collection time & June 27, 2001 & IDA \\
\hline MIGS-4.1 & Latitude & 38.9591667 & NAS \\
\hline MIGS-4.2 & Longitude & -85.8902778 & NAS \\
\hline MIGS-4.3 & Depth & $40-90 \mathrm{~cm}$ & NAS \\
\hline MIGS-4.4 & Altitude & 583 feet & NAS \\
\hline
\end{tabular}

aEvidence codes - IDA: Inferred from Direct Assay; TAS: Traceable Author Statement (i.e., a direct report exists in the literature); NAS: Non-traceable Author Statement (i.e., not directly observed for the living, isolated sample, but based on a generally accepted property for the species, or anecdotal evidence). These evidence codes are from the Gene Ontology project [24]. 


\section{Genome properties}

The 5,070,478- base pair genome of Arthrobacter FB24 is composed of a single 4,698,945-base pair circular chromosome and three large circular plasmids $(96,488,115,507$, and $159,536 \mathrm{bp}$ ) (Table 3) with GC content of 65.5, 64.7, 63.3 and $65.0 \%$, respectively. Based on a summary of genomic features listed on the Integrated Microbial Genomes (IMG) [34] there are 4,536 protein coding sequences identified, of which 3,279 (70.94\%, Table 4) have been assigned to a COG functional category (Table 5, Figure 3and Figure 4). There are 1,257 (27.19\%) predicted genes without an associated function.

\section{Genome sequencing and assembly}

The random shotgun method was used in Sanger sequencing the genome of Arthrobacter sp. strain FB24 at the DOE-Joint Genome Institution (DOEJGI). Medium ( $8 \mathrm{~kb}$ ) and small (3 kb) insert random libraries were partially sequenced with average success rate of $88 \%$ and average high-quality read lengths of 614 nucleotides. Sequences were assembled with parallel phrap (High Performance Software, LLC). Possible mis-assemblies were corrected with Dupfinisher [27] or by analysis of transposon insertions in bridge clones. Gaps between contigs were closed by editing, custom primer walk or PCR amplification. The completed genome sequence of Arthrobacter sp. FB24 contains 89530 reads, achieving an average of 15 -fold sequence coverage per base with an error rate less than 1 in 100,000. The sequences of Arthrobacter sp. FB24 can be accessed using the GenBank accession number NC_008541 for the chromosome and NC_008537, NC_008538, NC_008539 for three plasmids.

\section{Genome annotation}

Automated gene prediction was performed by using the output of Critica [28], combined with the output of Generation and Glimmer [29]. The assignment of product descriptions was made by using search results of the following curated databases in this order: TIGRFam; PRIAM ( $e^{-30}$ cutoff); Pfam; Smart; COGs; Swissprot/TrEMBL (SPTR); and KEGG. If there was no significant similarity to any protein in another organism, it was described as "hypothetical protein." "Conserved hypothetical protein" was used if at least one match was found to a hypothetical protein in another organism. EC numbering was based on searches in PRIAM at an $e^{-10}$ cutoff; COG and KEGG functional classifications were based on homology searches in the respective databases. Additionally, the tRNAScanSE tool [30] was used to find tRNA genes, whereas ribosomal RNAs were found by using BLASTn vs. the $16 \mathrm{~S}$ and $23 \mathrm{~S}$ ribosomal RNA databases. Other "standard" structural RNAs (e.g., 5S rRNA, rnpB, tmRNA, SRP RNA) were found by using covariance models with the Infernal search tool [31]. The HMMTOP program was used to predict the number of transmembrane segments (TMSs) in each protein. Those predicted to have two or more TMSs (about 918 proteins) were used to interrogate the transporter database (TCDB). Peter Karp's pathologic tool was used for pathway prediction [32]. This method largely relies on the keyword matching and other automatic methods to manually curate some of the pathways, such as aromatic compound degradation. Metabolic pathways were constructed using MetaCyc as a reference data set [33].

Table 2. Project information

\begin{tabular}{lll}
\hline MIGS ID & Property & Term \\
\hline MIGS-31 & Finishing quality & Finished \\
MIGS-28 & Libraries used & Small and medium random shotgun clones \\
MIGS-29 & Sequencing platforms & Sanger \\
MIGS-31.2 & Fold coverage & $\sim$ 15-fold \\
MIGS-30 & Assemblers & Parallel PHRAP \\
MIGS-32 & Gene calling method & Critica, Generation, Glimmer \\
& Genome Database release & March 1, 2007 \\
& Genbank ID & 12640 \\
& Genbank Date of Release & October 24, 2006 \\
& GOLD ID & Gc00445 \\
& Project relevance & Bioremediation, biotechnological, environmental \\
\hline
\end{tabular}


Table 3. Summary of genome

\begin{tabular}{lrlll}
\hline Label & Size (bp) & Topology & INSDC identifier & RefSeq ID \\
\hline Chromosome 1 & $4,698,945$ & Circular & CP000454.1 & NC_008541.1 \\
Plasmid pFB104 & 96,488 & Circular & CP000457.1 & NC_008539.1 \\
Plasmid pFB105 & 115,507 & Circular & CP000456.1 & NC_008538.1 \\
Plasmid pFB136 & 159,536 & Circular & CP000455.1 & NC_008537.1 \\
\hline
\end{tabular}

Table 4. Nucleotide content and gene count levels of the genome

\begin{tabular}{|c|c|c|}
\hline Attribute & Value & $\%$ of total ${ }^{\mathrm{a}}$ \\
\hline Genome size (bp) & $5,070,478$ & 100.0 \\
\hline DNA coding region (bp) & $4,552,065$ & 89.78 \\
\hline DNA G+C content $(b p)$ & $3,315,507$ & 65.39 \\
\hline Total genes ${ }^{b}$ & 4,622 & 100.00 \\
\hline RNA genes & 86 & 1.86 \\
\hline Protein-coding genes with function prediction & 3,279 & 70.94 \\
\hline Protein coding genes without function prediction & 1,257 & 27.19 \\
\hline Genes in paralog clusters & 965 & 20.88 \\
\hline Genes assigned to COGs & 3,361 & 72.72 \\
\hline Genes with signal peptides & 1,098 & 23.76 \\
\hline Genes with transmembrane helices & 1,168 & 25.27 \\
\hline Paralogous groups & 373 & 100.00 \\
\hline
\end{tabular}

a) The total is based on either the size of the genome in base pairs or on the total number of protein coding genes in the annotated genome.

b) Also includes 54 pseudogenes and 5 other genes 


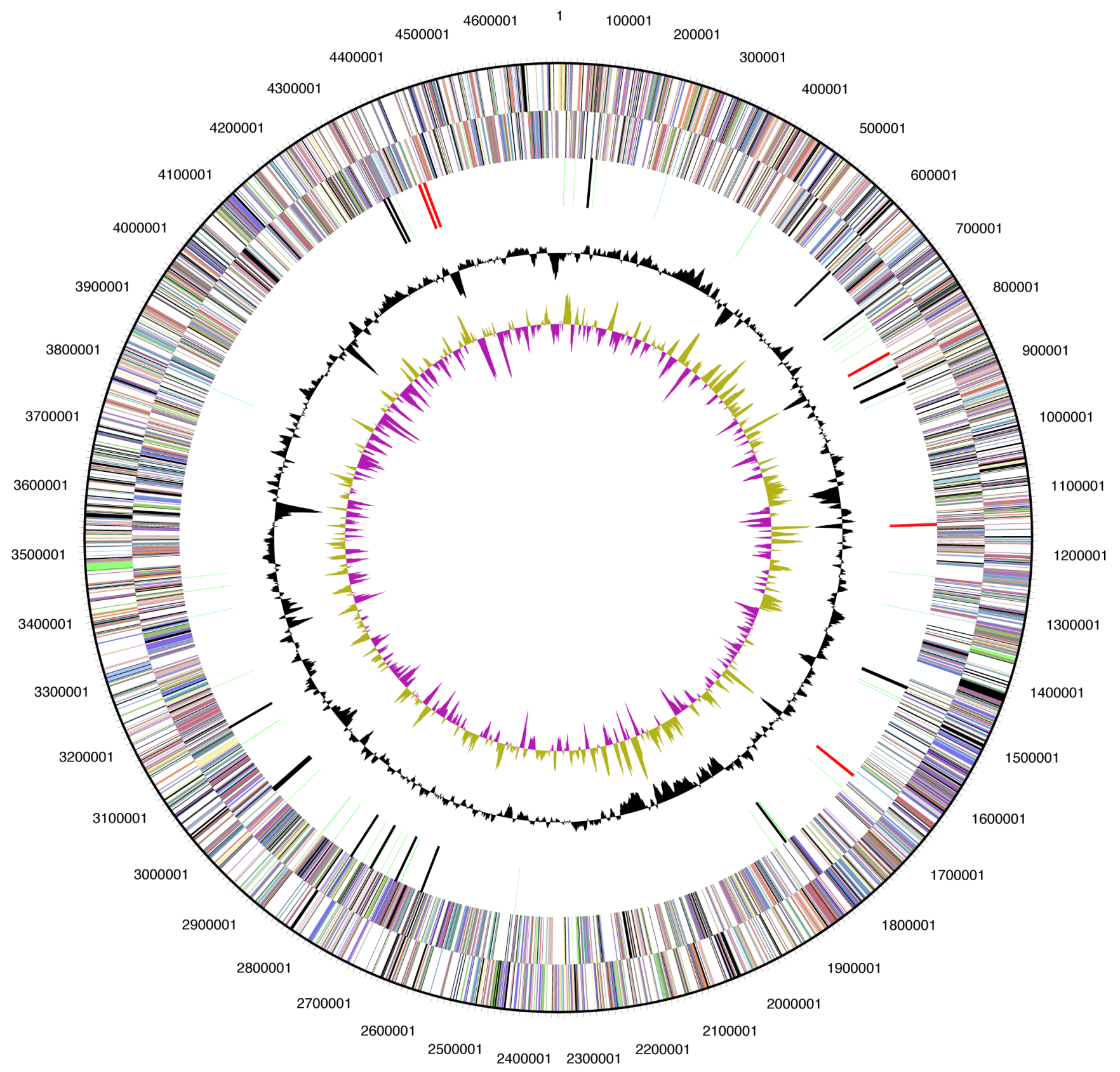

Figure 3. Circular map of FB24 chromosome, graphical depiction from outside to the center: genes on forward strand, genes on reverse strand (colored by COG categories), RNA genes (tRNAs green, rRNAs red, other RNAs black), GC content, GC skew. Chromosome is not to scale with plasmid maps. 


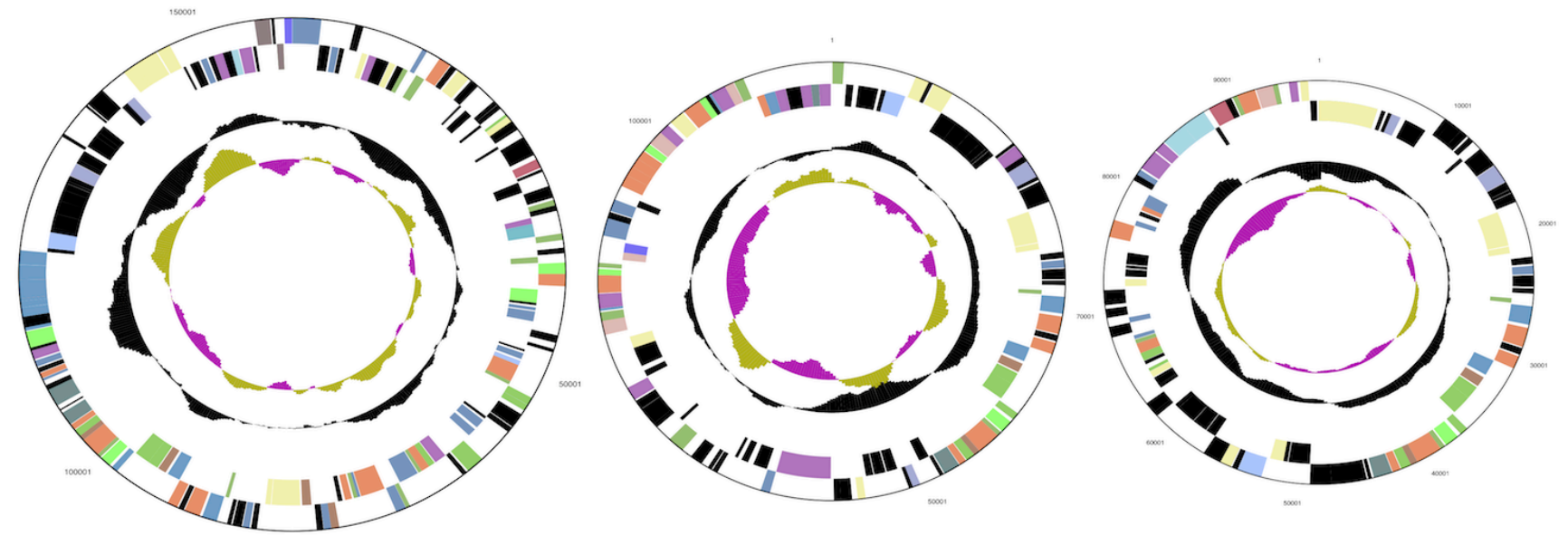

Figure 4. Circular map of three plasmids in FB24, graphical depiction from outside to the center: genes on forward strand, genes on reverse strand (colored by COG categories), RNA genes (tRNAs green, rRNAs red, other RNAs black), GC content, GC skew. Plasmid maps not to scale with each other or with chromosome map.

Table 5. Number of genes associated with general COG functional categories

\begin{tabular}{crrl}
\hline Code & Value & \%age & Description \\
\hline J & 162 & 4.27 & Translation, ribosomal structure and biogenesis \\
A & 1 & 0.03 & RNA processing and modification \\
K & 363 & 9.57 & Transcription \\
L & 164 & 4.32 & Replication, recombination and repair \\
B & 1 & 0.03 & Chromatin structure and dynamics \\
D & 32 & 0.84 & Cell cycle control, cell division, chromosome partitioning \\
Y & - & - & Nuclear structure \\
V & 49 & 1.29 & Defense mechanisms \\
T & 162 & 4.27 & Signal transduction mechanisms \\
M & 171 & 4.51 & Cell wall/membrane/envelope biogenesis \\
N & 3 & 0.08 & Cell motility \\
Z & 1 & 0.03 & Cytoskeleton \\
W & 0 & 0.0 & Extracellular structures \\
U & 48 & 1.27 & Intracellular trafficking, secretion, and vesicular transport \\
O & 124 & 3.27 & Posttranslational modification, protein turnover, chaperones \\
C & 239 & 6.3 & Energy production and conversion \\
G & 436 & 11.49 & Carbohydrate transport and metabolism \\
E & 364 & 9.6 & Amino acid transport and metabolism \\
H & 98 & 2.58 & Nucleotide transport and metabolism \\
I & 155 & 4.09 & Lipid transport and metabolism \\
P & 207 & 5.46 & Inorganic ion transport and metabolism \\
Q & 112 & 2.95 & Secondary metabolites biosynthesis, transport and catabolism \\
R & 458 & 12.07 & General function prediction only \\
S & 286 & 7.54 & Function unknown \\
- & 1,261 & 27.28 & Not in COG \\
\hline & & &
\end{tabular}

a) The total is based on the total number of protein coding genes in the annotated genome. 


\section{Genome comparisons}

A comparative analysis of genome sizes and protein coding genes in Arthrobacter sp. FB24 and other Arthrobacter species with finished sequences (Table 6) was made from data listed on the IMG website [34]. Included in the comparison is $A$. arilaitensis re117 (Gc01419, FQ311476) [8], A. aurescens TC1 (Gc00480, NC_008709) [9], A. chlorophenolicus A6 (Gc00930, NC_011886), A. nitroguajacolicus Rue61a (Gc0006272, CP003203), and A. phenanthrenivorans Sphe3 (Gc01621, CP002379) [10]. In addition, the draft genome of A. globiformis NBRC 12137 was included because its phylogenetic relatedness to FB24 based on the 16S rRNA gene sequence. Similarity between functional protein groups (based on COG, clusters of orthologous groups) in the genomes of these strains were made and visualized using hierarchical clustering (Figure 5) with tools available on the Joint Genome Institute (JGI) Integrated Microbial Genomes (IMG) site. Also included in the tree were closely related species in the family Micrococcaceae with finished genomes Kocuria rhizophila DC2201 (Gc00769), Microccus luteus Fleming NCTC 2665 (Gc01033), Renibacterium salmoninarum ATCC 33209 (Gc00698), Rothia dentocariosa ATCC 17931 (Gc01662), and Rothia mucilaginosa DY-18 (Gc01162). Detailed information about the genome properties and genome annotation of these strains can be obtained from the JGI-IMG website at the JGI website [35].

Table 6. Comparison of genomes of the genus Arthrobacter with finished genome sequences

\begin{tabular}{|c|c|c|c|c|c|c|c|}
\hline Genome Name & $\begin{array}{l}\text { Genome } \\
\text { size (bp) }\end{array}$ & $\begin{array}{l}\text { Gene } \\
\text { count }\end{array}$ & $\begin{array}{l}\text { Protein } \\
\text { coding }\end{array}$ & $\begin{array}{r}\text { Protein with } \\
\text { function }\end{array}$ & $\begin{array}{l}\text { Without } \\
\text { function }\end{array}$ & $\begin{array}{l}\text { Plasmid } \\
\text { number }\end{array}$ & $\begin{array}{r}\text { rRNA } \\
\text { operons }\end{array}$ \\
\hline $\begin{array}{l}\text { Arthrobacter arilaitensis re117, } \\
\text { CIP108037 }\end{array}$ & $3,918,192$ & 3,518 & 3,436 & 2,390 & 1,046 & 2 & 6 \\
\hline Arthrobacter aurescens TC1 & $5,226,648$ & 4,793 & 4,699 & 3,419 & 1,280 & 2 & 6 \\
\hline Arthrobacter chlorophenolicus A6 & $4,980,870$ & 4,744 & 4,641 & 3,125 & 1,516 & 2 & 5 \\
\hline Arthrobacter nitroguajacolicus Rue61a & $5,081,038$ & 4,655 & 4,584 & 3,800 & 784 & 2 & 6 \\
\hline Arthrobacter phenanthrenivorans Sphe3 & $4,535,320$ & 4,273 & 4,209 & 3,101 & 1,108 & 2 & 4 \\
\hline Arthrobacter sp. FB24 & $5,070,478$ & 4,622 & 4,536 & 3,279 & 1,257 & 3 & 5 \\
\hline Arthrobacter globiformis NBRC 12137* & $4,954,410$ & 4,582 & 4,529 & 2,784 & 1,745 & ? & 1 \\
\hline
\end{tabular}

*Sequence not fully assembled 


\section{Micrococcus luteus Fleming NCTC 2665}

Kocuria rhizophila DC2201

Arthrobacter globiformis NBRC 12137

- Arthrobacter nitroguajacolicus Rue61a

Arthrobacter aurescens TC1

Arthrobacter sp. FB24

Arthrobacter chlorophenolicus A6

Arthrobacter phenanthrenivorans Sphe3

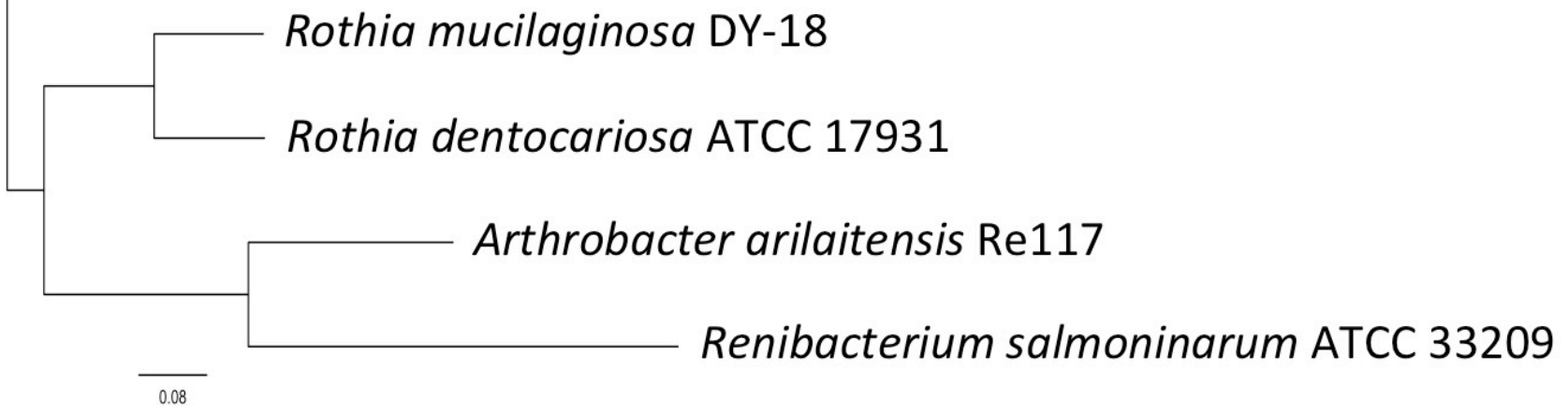

Figure 5. Hierarchical tree based on similarity of COG groups between genomes. Included are genomes of bacteria in the family Micrococcaceae with finished genome sequences.

\section{References}

1. Joynt J, Bischoff M, Turco RF, Konopka A, Nakatsu $\mathrm{CH}$. Microbial community analysis of soils contaminated with lead, chromium and organic solvents. Microb Ecol 2006; 51:209-219. PubMed http://dx.doi.org/10.1007/s00248-0050205-0

2. Nakatsu CH, Carmosini N, Baldwin B, Beasley F, Kourtev P, Konopka A. Soil microbial community responses to additions of organic carbon substrates and heavy metals ( $\mathrm{Pb}$ and $\mathrm{Cr}$ ). Appl Environ Microbiol 2005; 71:7679-7689. PubMed http://dx.doi.org/10.1128/AEM.71.12.7679$\underline{7689.2005}$

3. Henne KL, Nakatsu CH, Thompson DK, Konopka AE. High-level chromate resistance in Arthrobacter sp. strain FB24 requires previously uncharacterized accessory genes. BMC Microbiol
2009; 9:199. PubMed

http://dx.doi.org/10.1186/1471-2180-9-199

4. Henne KL, Turse JE, Nicora CD, Lipton MS, Tollaksen SL, Lindberg C, Babnigg G, Giometti CS, Nakatsu CH, Thompson DK, et al. Global proteomic analysis of the chromate response in Arthrobacter sp strain FB24. J Proteome Res 2009; 8:1704-1716. PubMed http://dx.doi.org/10.1021/pr800705f

5. Becker JM, Parkin T, Nakatsu CH, Wilbur JD, Konopka A. Bacterial activity, community structure, and centimeter-scale spatial heterogeneity in contaminated soil. Microb Ecol 2006; 51:220231. PubMed http://dx.doi.org/10.1007/s00248005-0002-9 
6. Kourtev PS, Nakatsu CH, Konopka A. Responses of the anaerobic bacterial community to addition of organic C in chromium(VI)- and iron(III)amended microcosms. Appl Environ Microbiol 2006; 72:628-637. PubMed http://dx.doi.org/10.1128/AEM.72.1.628$\underline{637.2006}$

7. Kourtev PS, Nakatsu CH, Konopka A. Inhibition of nitrate reduction by chromium( $\mathrm{VI})$ in anaerobic soil microcosms. Appl Environ Microbiol 2009; 75:6249-6257. PubMed http://dx.doi.org/10.1128/AEM.00347-09

8. Monnet C, Loux V. Gibrat J-Fo, Spinnler E, Barbe Vr, Vacherie B, Gavory F, Gourbeyre E, Siguier P, Chandler MI and others. The Arthrobacter arilaitensis Re117 Genome Sequence Reveals Its Genetic Adaptation to the Surface of Cheese. PLOS ONE 2010; 5:e15489. PubMed http://dx.doi.org/10.1371/journal.pone.0015489

9. Mongodin EF, Shapir N, Daugherty SC, Deboy RT, Emerson JB, Shvartzbeyn A, Radune D, Vamathevan J, Riggs F, Grinberg V, et al. Secrets of soil survival revealed by the genome sequence of Arthrobacter aurescens TC1. PLoS Genet 2006; 2:e214. PubMed http://dx.doi.org/10.1371/journal.pgen.0020214

10. Kallimanis A, LaButti K, Lapidus A, Clum A, Lykidis A, Mavromatis K, Pagani I, Liolios K, Ivanova N, Goodwin L, et al. Complete genome sequence of Arthrobacter phenanthrenivorans type strain (Sphe3T). Stand Genomic Sci 2011; 4:123-130. PubMed http://dx.doi.org/10.4056/sigs.1393494

11. Cole JR, Chai B, Farris RJ, Wang Q, Kulam-SyedMohideen AS, McGarrell DM, Bandela AM, Cardenas E, Garrity GM, Tiedje JM. The ribosomal database project (RDP-II): introducing myRDP space and quality controlled public data. Nucleic Acids Res 2007; 35:D169-D172. PubMed http://dx.doi.org/10.1093/nar/gkl889

12. Larkin MA, Blackshields G, Brown NP, Chenna R, McGettigan PA, McWilliam H, Valentin F, Wallace IM, Wilm A, Lopez R, et al. Clustal W and Clustal X version 2.0. Bioinformatics 2007; 23:2947-2948. PubMed http://dx.doi.org/10.1093/bioinformatics/btm404

13. Woese CR, Kandler O, Wheelis ML. Towards a natural system of organisms: proposal for the domains Archaea, Bacteria, and Eucarya. Proc Natl Acad Sci USA 1990; 87:4576-4579. PubMed http://dx.doi.org/10.1073/pnas.87.12.4576
14. Garrity GM, Holt JG. The Road Map to the Manual. In: Garrity GM, Boone DR, Castenholz RW, editors. Bergey's Manual of Systematic Bacteriology. Second Edition ed. Volume 1. New York: Springer; 2001. p 119-169.

15. Stackebrandt E, Rainey F, Ward-Rainey N. Proposal for a new hierarchic classification system, Actinobacteria classis nov. Int I Syst Bacteriol 1997; 47:479-491. http://dx.doi.org/10.1099/00207713-47-2-479

16. Zhi XY, Li WJ, Stackebrandt E. An update of the structure and $16 \mathrm{~S}$ rRNA gene sequence-based definition of higher ranks of the class Actinobacteria, with the proposal of two new suborders and four new families and emended descriptions of the existing higher taxa. Int / Syst Bacteriol 2009; 59:589-608. PubMed

17. Skerman VBD, McGowan V, Sneath PHA. Approved Lists of Bacterial Names. Int J Syst Bacteriol 1980; 30:225-420. http://dx.doi.org/10.1099/00207713-30-1-225

18. Buchanan RE. Studies in the nomenclature and classification of bacteria. II. The primary subdivisions of the Schizomycetes. J Bacteriol 1917; 2:155-164. PubMed

19. Pribram E. A contribution to the classification of microorganisms. J Bacteriol 1929; 18:361-394. PubMed

20. Conn HJ, Dimmick I. Soil bacteria similar In morphology to Mycobacterium and Corynebacterium. J Bacteriol 1947; 54:291-303. PubMed

21. Koch C, Schumann P, Stackebrandt E. Reclassification of Micrococcus agilis (Ali-Cohen 1889) to the genus Arthrobacter as Arthrobacter agilis comb. nov. and emendation of the genus Arthrobacter. Int J Syst Bacteriol 1995; 45:837839. PubMed http://dx.doi.org/10.1099/00207713-45-4-837

22. Keddie RM. Genus II. Arthrobacter Conn and Dimmick 1947, 300. In: Buchanan RE, Gibbons NE (eds), Bergey's Manual of Determinative Bacteriology, Eighth Edition, The Williams and Wilkins Co., Baltimore, 1974, p. 618-625.

23. Judicial Commission. Opinion 24. Rejection of the Generic Name Arthrobacter Fischer 1895 and Conservation of the Generic Name Arthrobacter Conn and Dimmick 1947. Int Bull Bacteriol Nomencl Taxon 1958; 8:171-172.

24. Ashburner M, Ball CA, Blake JA, Botstein D, Butler H, Cherry JM, Davis AP, Dolinski K, Dwight SS, Eppig JT, et al. Gene Ontology: tool for the 
unification of biology. Nat Genet 2000; 25:25-29. PubMed http://dx.doi.org/10.1038/75556

25. Field D, Garrity G, Gray T, Morrison N, Selengut J, Sterk P, Tatusova T, Thomson N, Allen MJ, Angiuoli SV, et al. The minimum information about a genome sequence (MIGS) specification. Nat Biotechnol 2008; 26:541-547. PubMed http://dx.doi.org/10.1038/nbt1360

26. Ausubel FM, Brent R, Kingston RE, Moore DD, Seidman JG, Smith JA, Struhl K, eds. Current Protocols in Molecular Biology. Hoboken NJ: John Wiley \& Sons; 2003.

27. Han C, Chain P. Finishing repetitive regions automatically with Dupfinisher. In: Arabnia HR, Valafar H, editors2006; Las Vegas, Nevada, USA. CSREA Press. p 142-147.

28. Badger JH, Olsen GJ. CRITICA: Coding region identification tool invoking comparative analysis. Mol Biol Evol 1999; 16:512-524. PubMed http://dx.doi.org/10.1093/oxfordjournals.molbev.a $\underline{026133}$

29. Delcher AL, Harmon D, Kasif S, White O, Salzberg SL. Improved microbial gene identification with GLIMMER. Nucleic Acids Res 1999; 27:4636-4641. PubMed http://dx.doi.org/10.1093/nar/27.23.4636
30. Lowe TM, Eddy SR. tRNAscan-SE: A Program for Improved Detection of Transfer RNA Genes in Genomic Sequence. Nucleic Acids Res 1997;25:0955-964.

31. Eddy SR. A memory-efficient dynamic programming algorithm for optimal alignment of a sequence to an RNA secondary structure. BMC Bioinform 2002;3.

32. Karp PD, Paley S, Romero P. The Pathway Tools software. Bioinformatics 2002; 18:S225-S232.

PubMed

http://dx.doi.org/10.1093/bioinformatics/18.suppl 1.S225

33. Caspi R, Foerster H, Fulcher CA, Hopkinson R, Ingraham J, Kaipa $\mathrm{P}$, Krummenacker $\mathrm{M}$, Paley $\mathrm{S}$, Pick J, Rhee SY, et al. MetaCyc: a multiorganism database of metabolic pathways and enzymes. Nucleic Acids Res 2006; 34:D511-D516. PubMed http://dx.doi.org/10.1093/nar/gkj128

34. Markowitz VM, Chen IMA, Palaniappan K, Chu K, Szeto E, Grechkin Y, Ratner A, Anderson I, Lykidis A, Mavromatis K, et al. The integrated microbial genomes system: an expanding comparative analysis resource. Nucleic Acids Res 2010; 38:D382-D390. PubMed http://dx.doi.org/10.1093/nar/gkp887

35. DOE Joint Genome Institute. http://img.jgi.doe.gov/cgi-bin/w/main.cgi 